\title{
Commentary
}

\section{Coming Up Short: Policewomen and Indirect Height Discrimination in EU Law}

By Uladzislau Belavusau, Senior Researcher in European Law, T.M.C. Asser Institute (The Hague) - University of Amsterdam, The Netherlands

\section{Introduction}

Physical requirements (appearance, weight, body strength, and so on) have long been under the looking glass of antidiscrimination law in Western jurisdictions. ${ }^{1}$ Although often labeled as bona fide occupational qualifications (genuine occupation requirements), they carry a strong suspicion of discrimination. Only a few jurisdictions, however, explicitly outline physical requirements as grounds of employment discrimination. ${ }^{2}$ Height and weight are not usually listed within the standard labor catalogue covering instead gender, ethnicity, religion, sexual orientation, age, and disability. Hence, more traditional grounds of discrimination (such as gender or disability) are bound to play the role of proxies in uncovering trait-based discrimination.

Excessive weight rather than low weight typically brings charges of discrimination. ${ }^{3}$ Height carries the opposite correlation. Studies on stature in psychology and sociology unequivocally show that shorter people are more likely to face discrimination than their taller compatriots, with employment patterns

1 Ritu Mahajan, "The Naked Truth: Appearance Discrimination, Employment, and the Law," 14 Asian American Law Journal (2007): 165 .

2 E.g., Equal Opportunity Act 2010 in Victoria, Australia. See Elizabeth M. Adamitis, "A Proposal to Prohibit Appearance Discrimination in Employment," Washington Law Review 75 (2000): 195 .

3 Mark V. Roehling, "Weight-Based Discrimination in Employment: Psychological and Legal Aspects," Personnel Psychology $5^{2}$ (1999): 969 . 
often imitating biological dispositions about size among animals. ${ }^{4}$ Social hierarchies are thus clearly height-bound, permeating our public image, wages, choice of work partners, and even success of presidential candidates. ${ }^{5}$

The stigma of short stature in employment has particular repercussions for women, as is well demonstrated in the recent case of Esoterikon et al. v. Kalliri of the Court of Justice of the European Union. ${ }^{6}$ Ms. Maria-Eleni Kalliri brought a complaint before the administrative court in Greece for being rejected for police training on the basis of her height. The default requirement for such applicants under Greek rules was 170 centimeters for both men and women. Ms. Kalliri fell short of this criterion by 2 centimeters. She complained that her dismissal was a matter of sexual discrimination, given that men are on average more likely to satisfy this requirement. The lower tribunal found this instance to be discrimination. A higher Greek court, however, requested a preliminary ruling from the Court of Justice of the European Union (CJEU) on whether the height requirement indeed constitutes sex discrimination under EU law.

This case is not the first occasion that the CJEU has had to scrutinize traitbased discrimination. However, the preliminary reference has resulted in the first judgement by the CJEU on height requirement as amounting to indirect discrimination of women. In this regard, the case of Fag og Arbejde (2014) has been perhaps the most cited concerning alleged weight discrimination. ${ }^{7}$ In that case the CJEU rejected the interpretation that weight requirements in employment constitute discrimination, but left it to national courts to assess whether specific instances of weight-based choices by employers may constitute discrimination on grounds of disability. In this regard, the Kalliri case is a far stronger affirmation of a link between height and gender than that between weight and disability in Fag of Arbejde. Likewise, Kalliri is not the first case to reach the CJEU about hiring practices in police units. The Court previously had to assess whether a maximum age requirement (of thirty-five years) may constitute direct discrimination for employment as police officers who are to

4 Nicola Persico, Andrew Postlewaite \& Dan Silverman, "The Effect of Adolescent Experience on Labour Market Outcomes: The Case of Height," Journal of Political Economy 112 (2004): 1019. According to the study, not only taller workers receive a wage premium but the disparity in height produces effects similar to race and gender gaps.

5 Stewart J.H. McCann, "Height, Societal Threat, and the Victory Margin in Presidential Elections (1824-1992)," Psychological Reports 88 (2001): 741-742; Isaac B. Rosenberg, "Height Discrimination in Employment," Utah Law Review 3 (2009): 907.

6 Court of Justice of the European Union (First Chamber), Ypourgos Esoterikon et al. v. MariaEleni Kalliri, Case C-409/16, 18 October 2017.

7 Court of Justice of the European Union (Fourth Chamber), Fag og Arbejde, Case C-354/13, 18 December 2014. 
perform all the operational duties. ${ }^{8}$ The Court found the measure compatible with EU law. ${ }^{9}$

Furthermore, it is not entirely uncommon for courts in Europe to establish a height requirement as indirect discrimination of women. In September 2005, for example, a Swedish labor court fined its national car producer Volvo for rejecting a female applicant for not matching Volvo's height minimum. ${ }^{10}$ The Equal Opportunities Ombudsman, who brought this case, demonstrated that statistically men were several times more likely to reach the gender-neutral height requirement by Volvo than women. As for comparative labor and antidiscrimination law, the us Supreme Court delivered a precedent judgment on a similar matter as early as 1977 in Dothard $v$. Rawlison, rejecting height as a bona fide occupational qualification under Title VII of the Civil Rights Act of $1964 .{ }^{11}$ In that case, the Supreme Court established that height and weight standards were unnecessary for the effective job performance of prison guards, but sustained the gender-based employment of guards for men's and women's prisons as a genuine occupational requirement.

\section{Key Issues}

The CJEU first had to determine whether the legislation at issue falls within the scope of application of EU law, in that the dispute concerns Greek administrative acts adopted in 2007, and the period of transposition of Directive 2006/54 expired on 16 August 2008. ${ }^{12}$ In addition, pursuant to Article 34(1) of that directive, Directive 76/207 was repealed effective 15 August 2009. The Court therefore established that the provisions applicable ratione temporis to the facts of the main proceedings are not those of Directive 2006/54 but those of Directive $76 / 207 \cdot{ }^{13}$ The Court further confirmed that Directive $76 / 207$ applies to a person seeking employment, and also in regard to the selection criteria and recruitment conditions of such employment. ${ }^{14}$

8 Court of Justice of the European Union (Grand Chamber), Salaberria Sorondo, Case C-258/15, 15 November 2016.

9 The Court, however, came to a different conclusion in its in Case C-416/13 Vital Pérez, 13 November 2014, precluding national legislation which sets the maximum age for the recruitment of local police officers at 30 years.

10 Swedish Labour Court (Arbetsdomstolen), Case Dom-87/05 Volvo, 21 September 2005.

11 Us Supreme Court, 433 US 321 Dothard v. Rawlison, 27 June 1977.

12 Kalliri, $\$ 18$.

13 Ibid., §19-20.

14 Ibid., §23. 
Second, the CJEU had to assess the type of discrimination at stake. It ruled out direct discrimination because the height requirement was the same for both sexes. ${ }^{15}$ It therefore had to assess whether this requirement could constitute indirect discrimination. The referring court found in its decision that far more women than men are shorter than 1.70 meters, which clearly places women at a disadvantage. The CJEU concluded that the Greek law at issue in the main proceedings constitutes indirect discrimination. ${ }^{16}$

Third, the Court looked into whether this type of indirect discrimination can be objectively justified by a legitimate aim, and whether the method of achieving that aim was appropriate and necessary. ${ }^{17}$ The Greek government submitted that the intent of the law at issue was to enable the effective accomplishment of the tasks of the Greek police and that possession of certain particular physical attributes, such as a minimum height, was a necessary and appropriate condition of achieving that aim..$^{18}$ In this regard, the Court has already held that the concern to ensure the operational capacity and proper functioning of the police services indeed constitutes a legitimate objective. ${ }^{19}$ The Court observed, however, that the arrest and custody of offenders and the conduct of crime prevention patrols may require physical force. Nonetheless, certain police functions, such as providing assistance to citizens or traffic control, do not clearly require significant physical force. ${ }^{20}$ Furthermore, even if all the functions carried out by the Greek police required a particular physical aptitude, such an aptitude is not necessarily associated with a certain minimum height, nor do shorter persons naturally lack that aptitude. ${ }^{21}$ In particular, the Court pointed out that until 2003, Greek law on admission to the police force stipulated different minimum heights for men and women: 165 centimeters for women and 170 centimeters for men. Similarly, different minimum heights are defined for men and women in the port police and coast guard. ${ }^{22}$ The Court therefore considered that the aim pursued by the Greek law could be achieved in ways less disadvantageous to women, such as preselection on the basis of tests to assess physical ability. ${ }^{23}$

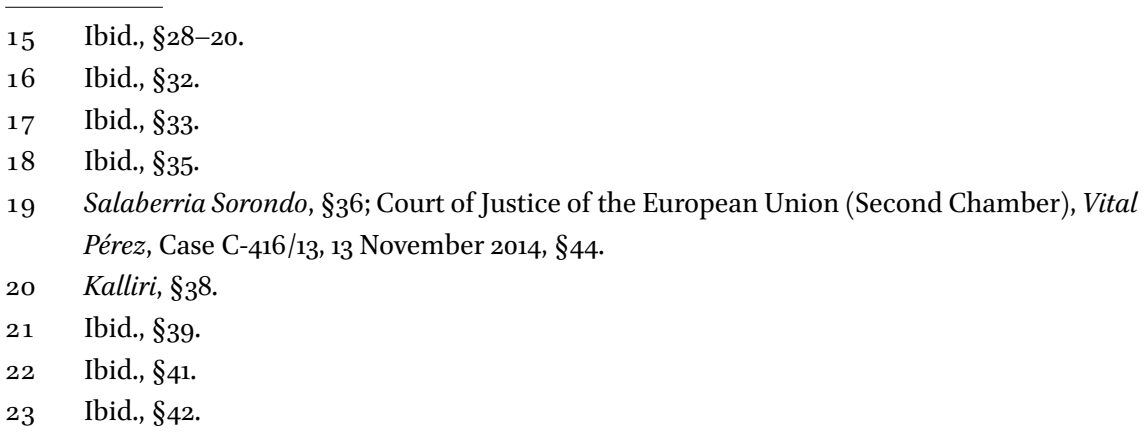


In light of these considerations, the Court ruled that the Greek law on police admissions constituted indirect discrimination under EU law because it worked to the disadvantage of far more women than men and did not appear to be either appropriate or necessary.

\section{Conclusions}

Kalliri was the first occasion that the Court of Justice discussed height as a matter of sexual discrimination. The outcome in Kalliri is somewhat predictable, in that it is difficult to imagine a more emblematic example of indirect discrimination of women than based on height. Yet the case also points to a wider problem, namely, of heightism - along with sexism or racism-as a widespread phenomenon rarely contested by law. The Kalliri case leaves open a Pandora's box in EU antidiscrimination law in two respects.

First, although the Court rejects height justifications as unequivocally related to physical aptitude, it remains unclear when height would actually merit such a bona fide requirement status (technically allowed by EU equality directives). Looking at the inconsistent jurisprudence of the Court on age discrimination regarding employment in police units, ${ }^{24}$ and the employment of women in the military, ${ }^{25}$ it remains to be seen whether height requirements will survive in some elite forces. This judgment certainly seems to necessitate a more gender-differentiated imposition of height requirements to avoid accusations of indirect discrimination.

Second, using gender as a proxy to establish height discrimination raises the question of whether other traditional grounds of discrimination are suitable in this respect. In particular, race and ethnicity may well be statistically proven as related to height discrimination, giving rise to similar cases based on EU Race Equality Directive (2000). ${ }^{26}$ Although it is statistically plausible that men are more likely to reach a height of 170 centimeters, it would be equally easy to prove that people of Chinese origin are less likely to reach that height than those of Dutch ethnicity, for example. Kalliri thus contributes to a wider debate on the use of trait-based requirements, such as weight and appearance, in employment.

\footnotetext{
24 Cf. Salaberria Sorondo; Vital Pérez.

25 Cf. Court of Justice of the European Union, Kreil, Case C-285/98, 11 January 200o; Sidar, Case C-273/97, 26 October 1999 .

26 Council Directive 2000/43 / EC of 29 June 2000 implementing the principle of equal treatment between persons irrespective of racial or ethnic origin [2000] oJ L180/22.
} 